\title{
Development and Evaluation of Nutri-Dense Chocolates for Pre-Schoolers
}

\author{
D. Barbhai Mrunal* and D. Vijayalakshmi \\ Department of Food Science and Nutrition, University of Agricultural Sciences, GKVK, \\ Bengaluru-65, Karnataka, India \\ *Corresponding author
}

\begin{abstract}
A B S T R A C T
Keywords

Pre-schoolers, Food jags, Nutri-dense,

White chocolate,

Sensory evaluation

Article Info

Accepted:

24 February 2018

Available Online:

10 March 2018

Pre-schoolers are the children between 1-6 years of age group. Malnutrition is major problem faced if diet lacks in quantity or quality. They develop food jags, refusing previously accepted food or asking for the same food each meal. Chocolates are most popular products amongst pre-schoolers, which they are fond of consuming. White chocolate commonly consists of cocoa butter, sugar and milk solids and is characterized by a pale yellow or ivory appearance. Thus, present study was conducted with objective to formulate nutrient dense chocolate for pre-schoolers. Three variations of white chocolate viz., WC1, WC2 and WC3 were prepared with incorporation of nutri mix in chocolate compound at 40, 50 and 60 per cent levels respectively. Prepared product was evaluated by 21 semi trained panel members for organoleptic parameters with 9-point hedonic scale. Results revealed that WC 2 was best accepted with sensory score of 8.33. The nutrient analysis showed that $100 \mathrm{gm}$ of white chocolates had $500 \mathrm{Kcal}$ of energy, $7.70 \mathrm{gm}$ of protein, $23.50 \mathrm{gm}$ of fat, $21.50 \mathrm{mg}$ of calcium and $4.36 \mathrm{mg}$ of iron. Thus, it can be concluded that commercially available chocolates can be made more nutrient rich by incorporation of food groups.
\end{abstract}

\section{Introduction}

Preschool children (1-6yrs.) constitute one of the most nutritionally vulnerable segments of the population. Being vulnerable they succumb readily to infection where diet is poor in quantity and quality. National Family Health Survey- 4 (2015-16), India fact sheet for children under 5years in urban area reported that 31 per cent were stunted, 20 per cent wasted, 7.5 percent severely wasted and 29.1 per cent underweight and in rural area 41.2 per cent were stunted, 21.5 per cent wasted, 7.4 per cent severely wasted and 38.3 per cent under weight. They develop food jags during this time, refusing previously accepted food or asking for the same food each meal. Most of the children eat four to six times a day making snacks as important meals in contributing to the total daily nutrient intake (Krause's, 2000). Snacks should be chosen wisely so that they are dense in nutrients to fulfil their daily requirements. The growth is generally slower during these years than first year of life but continues gradually. Because growth is slower, the appetite decreases, which often concerns the parents. Children have decreased interest in food and increased 
interest in world around them. They are fond of nibbling in between the meals and love eating chocolates, fast foods etc. Hence, it is important to formulate nutrient dense foods for preschool children to overcome the problem of under nutrition.

Nutrient density in the food refers to the amount of nutrient in the food in comparison to the calories. Nutrient dense foods contain small share of the calories from the fats, sugar or refined flours and have more proteins, vitamins and minerals. Energy dense foods have lots of calories per serving whereas nutrient dense foods have high levels of nutrients per serving. Some examples of nutrient dense food include whole-grain products, fruits, vegetables, milk and milk product etc. Combination of various food groups can enhance the nutritive value of different food products. Hence with a view to reduce malnutrition in preschool children, nutrient dense products were formulated under present study.

\section{Materials and Methods}

\section{Formulation of product}

Nutri mix was prepared by adding rice flakes, cashew nut, groundnut, roasted bengal gram, tuti-fruity and chopped dates. This nutri mix was added to molten white chocolate at different levels viz., 40 (WC 1), 50 (WC 2) and 60 (WC 3) per cent and mixed properly. This mixture was poured immediately in the chocolate moulds and allowed to set in refrigerator for 15-20 mins. Chocolate without the nutri mix was considered as control.

\section{Sensory evaluation}

A 9-point hedonic scale (Peryam and Pilgrim, 1957) was used for organoleptic evaluation. The products were evaluated for their appearance, texture, colour, aroma/flavour, taste and overall acceptability by 21 semi trained panel members.

\section{Nutrient analysis}

Nutrient analysis of the developed products for moisture, ash, protein, fat, crude fibre calcium was done using AOAC (1980) methods. Estimation of minerals like iron, copper, zinc, magnesium and manganese were done by using AAS (Atomic Absorption Spectrophotometer) method. Estimation of $\beta$ carotene and vitamin $\mathrm{C}$ was done as per method quoted by Ranganna (1996).

\section{Statistical analysis}

Statistical analysis was done using Complete Randomised Design and one-way analysis of the variance. Significance was noted at 5 per cent level.

\section{Cost calculation}

Cost of best accepted white chocolate was calculated by considering the cost of the raw material purchased from local market, 30 per cent overhead costs which includes labour charge, electricity, machinery, packaging cost, etc. and 15 per cent of profit was added to the production cost, then the total price was calculated for $100 \mathrm{~g}$ of the product.

\section{Results and Discussion}

\section{Sensory evaluation}

Sensory evaluation scores of the white chocolates are shown in Figure 1. It was observed that WC 2 variation with 50 per cent mix scored higher values for all sensory attributes viz., appearance (8.38), colour (8.42), texture (8.38), aroma (8.19), taste (8.33) and overall acceptability (8.38) as compared to control samples. WC2 was well balanced with optimum quantity of nuts, dates 
and tuti-fruity, wherein nuts and dates gave the crunchy texture and tuti-fruity added juicy taste this could be possible reason for best acceptability of WC2. Chocolates without the addition of the mix were treated as control.

Sensory scores for taste and overall acceptability revealed that, WC 2 was best accepted $(8.33,8.38)$, followed by WC1 (8.09, $8.19)$, control $(7.95,8.14)$ and least score was obtained by WC $3(7.71,7.80)$. Variation WC 3 with 60 per cent mix scored the least rank as the extra nutty and chewy texture was not liked by the panel members. Similar results were quoted by Farooqui et al., (2014) for the optimised coconut milk chocolates where the texture and taste were enhanced due to addition of coconut milk.

\section{Nutrient Analysis}

Nutrient content of white chocolate and control is represented in Table 1. Nutritive value of $100 \mathrm{~g}$ WC 2 chocolates for protein, fat, energy and iron was $7.70 \mathrm{~g}, 23.5 \mathrm{~g}, 500$ Kcal and $4.36 \mathrm{mg}$ respectively, and is able to meet one third requirement of pre-schoolers for protein, fat, energy and iron (4-6 yrs. RDA, 2010). $100 \mathrm{~g}$ of white chocolate WC2 contain8 pieces approximately. The preschool children can consume 2-3 chocolates at one time. Nutrient content was enhanced due to addition of nuts, dates, rice flakes and roasted bengal gram. Thus, WC2 variation of white chocolate can prove to be a better choice in comparison to the plain milk chocolates generally available. Control chocolates was more energy dense as compared to the WC 2 variation viz., $523 \mathrm{Kcal}$ and $500 \mathrm{Kcal}$ respectively, but other nutrients were higher in the WC 2 variation as the formulation included combination of cereal, pulse, nuts and fruits. Mineral composition of white chocolate WC 2 for calcium $(21.50 \mathrm{mg})$, iron (4.36), magnesium $(8.00 \mathrm{mg})$, copper $(1.90 \mathrm{mg})$, manganese $(0.60 \mathrm{mg})$ and zinc $(1.01$ $\mathrm{mg}$ ) was higher than control sample with $8.23 \mathrm{mg}$ calcium, $0.58 \mathrm{mg}$ of iron, $2.20 \mathrm{mg}$ magnesium, $0.03 \mathrm{mg}$ manganese and $0.78 \mathrm{mg}$ zinc. $\beta$-carotene and Vitamin $\mathrm{C}$ content was $31.50 \mu \mathrm{g}$ and $3.10 \mathrm{mg}$ respectively in $\mathrm{WC} 2$ and no values were recorded for control sample. Presence of $\beta$-carotene and Vitamin C could be due to the tuti-fruity and dates used in the WC2 chocolates. Tarar (2007) reported higher values for protein (12.52-12.63) in chocolate with dates and vetch flour. Bharadwaj et al., (2016) reported higher amount of Vit. C (122 mg / $100 \mathrm{~g})$ content in guava milk Chocolates

Fig.1 Mean sensory scores of white chocolates

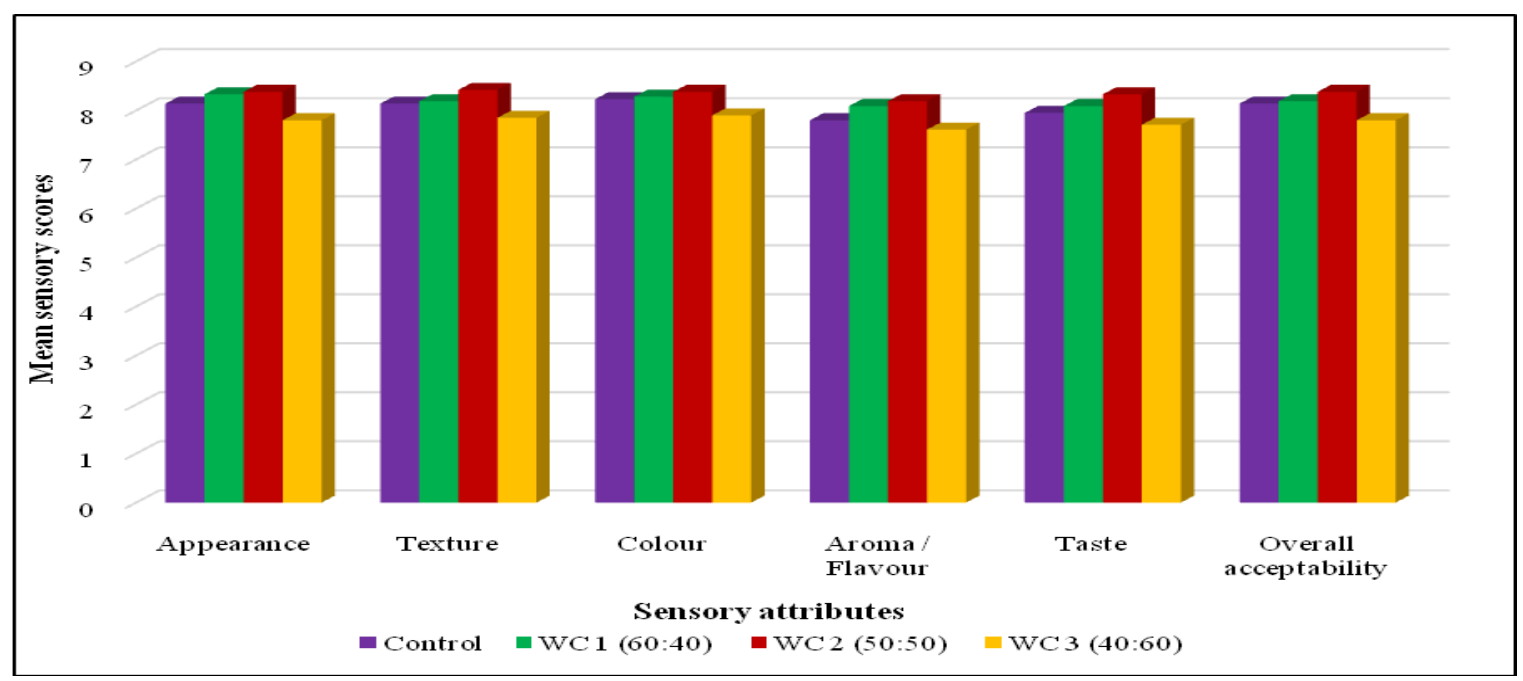


Table.1 Nutrient composition of white chocolates (per $100 \mathrm{~g}$ )

\begin{tabular}{|l|c|c|c|c|c|}
\hline \multicolumn{1}{|c|}{ Nutrients } & Control & WC 2 (50:50) & F-value & SEm+ & CD at 5 \% \\
\hline Moisture (\%) & 5.65 & 9.16 & $*$ & 0.043 & 0.168 \\
\hline Protein $(\mathrm{g})$ & 4.50 & 7.70 & $*$ & 0.092 & 0.360 \\
\hline Fat $(\mathrm{g})$ & 30.00 & 23.50 & $*$ & 0.067 & 0.264 \\
\hline Crude Fibre $(\mathrm{g})$ & 0.67 & 1.01 & $*$ & 0.016 & 0.061 \\
\hline Carbohydrate $(\mathrm{g})$ & 58.38 & 56.64 & $*$ & 0.355 & 1.393 \\
\hline Energy(Kcal) & 523 & 500 & $*$ & 1.080 & 4.241 \\
\hline Ash $(\mathrm{g})$ & 0.80 & 1.99 & $*$ & 0.041 & 0.161 \\
\hline Calcium $(\mathrm{mg})$ & 8.23 & 21.50 & $*$ & 0.166 & 0.652 \\
\hline Iron $(\mathrm{mg})$ & 0.58 & 4.36 & $*$ & 0.048 & 0.189 \\
\hline Magnesium $(\mathrm{mg})$ & 2.20 & 8.00 & $*$ & 0.082 & 0.322 \\
\hline Copper $(\mathrm{mg})$ & 0.00 & 1.90 & $*$ & 0.006 & 0.024 \\
\hline Manganese $(\mathrm{mg})$ & 0.03 & 0.60 & $*$ & 0.021 & 0.082 \\
\hline Zinc $(\mathrm{mg})$ & 0.78 & 1.01 & $*$ & 0.011 & 0.044 \\
\hline$\beta$-Carotene $(\mu \mathrm{g})$ & 0.00 & 31.50 & $*$ & 0.204 & 0.801 \\
\hline Vit C $(\mathrm{mg})$ & 0.00 & 3.10 & $*$ & 0.108 & 0.424 \\
\hline
\end{tabular}

*Significant at $5 \%$ level

Cost calculation for best accepted white chocolates

Cost for the best accepted white chocolates was calculated taking into consideration the cost of ingredients from local market, and 30 per cent overhead charges. Fifteen per cent profit was added to the production cost. The cost of $100 \mathrm{~g}$ white chocolate was Rs. 44.00 . Cost of chocolates was less than that of the ones available in the market.

Preschool children are fond of eating chocolates which can be made more nutrient rich by incorporation of different food groups (cereals, pulses, nuts and oilseeds, fruits, fats and oils). The present study carried out on development of nutrient dense chocolates for preschool children revealed that combination of different food groups can improve the nutrient content of foods which pre-schoolers are fond of munching and snacking. Enhancement in the sensory attributes was observed in the prepared products than control samples. Thus, it is necessary to prepare different products by value addition and commercialize it to overcome the problem of malnutrition in pre-schoolers.

\section{References}

A. O. A. C., 1980, Official methods of analysis 13th Edn. Association of Official Analytical chemists, Washington, D.C.

Anonymous, 2015-16, NFHS-4: National Family Health Surveys, National fact sheet - India. www.nfhsindia.org.

Bharadwaj, R, Mishra, D., Chauhan, A. K., Kumar, P. and Yadav, D., 2016, Optimization of Guava Milk Chocolate Using Response Surface Methodology, Biosci. Biotechnol. Res. Asia, Vol. 13(3): 1715-1723.

Farooqui, M. U., Raheem, M.I.A. and Masih, D., 2014, Development and Quality Evaluation of Coconut Milk Chocolate by Incorporation of Fat and Corn Flour. Int. J. Scientific Res., 3(8): 490-492. 
Gopalan, C., Rama Sastri, B. V. and Balasubramanian, S. C., 2014, Nutritive value of Indian foods. National Institute of Nutrition, Indian Council of Medical Research. Hyderabad, India. 40-95.

Krause's, 2000, Nutrition in Childhood. In: Food, Nutrition and Diet Therapy, pp: 271-272.

Preyam, D. R. and Pilgrim, F. J., 1957, Hedonic scale Method of Measuring Food Preferences. Food Technol., 11(9): 1-13.
Ranganna, S., 1996, Handbook of analysis and quality control for fruits and vegetable products. $2^{\text {nd }}$ Edn. Tata McGraw-Hill, Pub. Co. Ltd., New Delhi, pp. 84-86.

Tarar, O. M., 2007, Development, Characterization and Shelf Life Optimization of a Prototype Nutrient Dense Food Bar. M.Sc. Thesis. National Institute of Food Science and Technology, University of Agriculture, Faisalabad, Pakistan.

\section{How to cite this article:}

Barbhai Mrunal, D. and Vijayalakshmi, D. 2018. Development and Evaluation of Nutri-Dense Chocolates for Pre-Schoolers. Int.J.Curr.Microbiol.App.Sci. 7(03): 2748-2752. doi: https://doi.org/10.20546/ijcmas.2018.703.317 